\title{
Bozok Üniversitesi Sağlık Yüksek Okulu Öğrencilerinde Hepatit-B ve C Seroprevelanslarının Araștırılması
}

\author{
Investigation of Hepatitis-B and C Seroprevelances in Bozok University School of Health \\ Students
}

\author{
Çiğdem KADER1, Sadiye YOLCU2, Ayşe ERBAY1, Nazan KILIÇ AKÇA3, Selda YÜZER33, Sevinç POLAT3

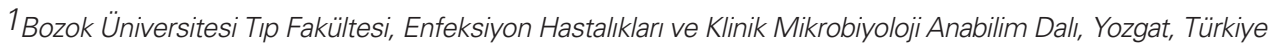 \\ 2 Bozok Üniversitesi Tıp Fakültesi, Acil Tıp Anabilim Dalı, Yozgat, Türkiye

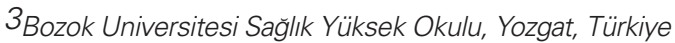

\section{ÖZET}

Amaç: Sağlık çalışanları için özellikle diş hekimliği, hemşirelik ve ebelik öğrencilerinde iğne gibi delici kesici aletlerle oluşan kan kaynaklı mesleki maruziyet patojenleri (hepatit $\mathrm{B}$, hepatit $\mathrm{C}$ ve HIV) güncel bir konudur. Bu prospektif çalışmanın amacı Bozok Üniversitesi Sağlık Bilimleri Yüksek Okulu öğrencilerinde Hepatit B ve Hepatit C ve HIV seroprevelanslarını değerlendirmek, öğrencilerin bu konudaki bilinç düzeylerini belirlemek, ayrıca, HBV bağışıkıı̆ı olmayan öğrencileri belirleyip onları aşılamaktır.

Gereç ve Yöntemler: Çalışmamızda, 01.02.2013-10.04.2013 tarihleri arasında Sağıı Yüksek Okulu Öğrencilerine anket uygulandı ve HBsAg, AntiHBs, Anti-HBclgG ve Anti-HCV sonuçlarılya birlikte değerlendirildi.

Bulgular: Sağlık Yüksek Okulunda okumakta olan 142 öğrenci çalışmaya alındı. Öğrencilerin 80'i $(\% 56,3)$ 1. sınıf, $42^{\prime}$ si $(\% 29,6)$ 2. sınıf, 9'u $(\% 6,3)$ 3. sınıf, 11'i $(\% 7,8)$ 4. sınıfta okumaktaydı ve $115^{\prime}$ i (\%81) kı, 27 'si (\%19) erkekti, yaş ortalamaları $20,1 \pm 1,8(18-25$ arası) idi. HBsAg $2(\% 1,4)$, AntiHBs $127(\% 89,4)$ ve Anti-HBclgG $9(\% 6,3)$ öğrencide pozitif saptandı. AntiHCV, öğrencilerin tümünde negatifti. Sarılık geçirdiğini söyleyen 7 kişiden $2(\% 28,6)$ 'sinin Anti-HBclgG değeri pozitif bulundu, sarlık geçirmediğini söyleyen 135 kişiden $7(\% 5,2)$ 'sinin Anti-HBclgG'si pozitif bulundu $(p=0,013)$. Anti-HBclgG değeri pozitif bulunan 9 öğrenciden ikisinin HBsAg pozitif kaldığı 7'sinde ise Anti-HBs'nin pozitifleşmiş olduğu tespit edildi. Anti-Hbs pozitifliği olan 127 öğrenciden 120'sinin (\%94,5) aşılama ile bağışıklık kazanmış olduğu bulundu. HBsAg, Anti-HBclgG ve Anti-Hbs negatif bulunan $13(\% 9,2)$ öğrenci hepatit B aşılama programına alındı.

Sonuç: Sonuç olarak sağlık personeli HBV ve HCV açısından risk altındadır. HBV enfeksiyonu aşı ile önlenebilir bir hastalık olduğu için tüm çalışanların eğitimi ve bağışık olmayan kişilerin aşılanması önem taşımaktadır. (Viral Hepatit Dergisi 2012; 19(2): 49-53)

Anahtar Kelimeler: Hepatit B, hepatit C, seroloji, seroprevelans, sağlık çalışanı

\begin{abstract}
Objective: The risk of occupational exposure to blood borne pathogens (hepatitis $\mathrm{B}$ and hepatitis $\mathrm{C}$ ) via sharp injuries such as needle stick injuries among health care workers, especially dental, nursing and midwifery students is a challenging issue. The aim of this prospective study is to evaluate the hepatitis $B$ and hepatitis C seroprevelances of students in Bozok University High School of Health, to investigate the level of conscious on this issue and also to determine nonimmunised students and to vaccine them.
\end{abstract}

Materials and Methods: In our study, a questionnaire form was applied to students of Bozok University High School of Health between February 2013-April 2013 and answers were evaluated with their HBsAg, Anti-Hbs, Anti-HBclgG and Anti-HCV results.

Results: One hundred and forty two students were included to the study. 80 $(56.3 \%)$ students were studying at 1 st class, $42(29.6 \%)$ students were at 2 nd class, $9(6.3 \%)$ were at $3^{\text {rd }}$. Class and $11(\% 7.8)$ were at $4^{\text {th }}$. class. $115(81 \%)$ students were female, $27(19 \%)$ students were male, mean age was $20.1 \pm 1.8(18-25)$. Two (1.4\%) students were HBsAg positive,127 (89.4\%) students were anti-HBs positive and nine $(6.3 \%)$ students were anti-HBclgG positive. Anti-HCV was negative in all students. Two (28.6\%) of seven students' anti-HbclgG values were positive who were exposured jaundice during childhood ( $p=0.013$ ). Two of nine students' $\mathrm{HBsAg}$ positivity remained whose anti-HBclgG value were positive, seven of these nine students Anti-HBs values became positive. 120 (94.5\%) of 127 Anti-HBs positive students had been acquired immunization by vaccine. $13(9.2 \%)$ students were taken into vaccine program whose $\mathrm{HBsAg}$, Anti-HBclgG and Anti-Hbs values were negative.

Conclusion: In conclusion, health workers are under risk for HBV and HCV. Education, determining the immunisation of nonimmunised of all health workers are so important because hepatitis B is a vaccine-preventable disease. (Viral Hepatitis Journal 2013; 19(2): 49-53)

Key words: Hepatitis B, hepatitis C, serology seroprevelance, healthcare worker

Yazıșma Adresi/Address for Correspondence: Dr. Çiğdem Kader, Bozok Üniversitesi Tıp Fakültesi, Enfeksiyon Hastalıkları ve Klinik Mikrobiyoloji Anabilim Dalı, Yozgat, Türkiye Tel.: +90 5079877031 E-mail: dr_cigdemtr@yahoo.com Geliş tarihi/Received: 09.04.2013 Kabul tarihi/Accepted: 30.05 .2013 


\section{Giriş}

Hepatit B virüsü (HBV), kan ya da vücut sıvılarıyla parenteral temas, perinatal bulaş, enfekte kişilerle temas ve cinsel temas yoluyla bulaşmaktadır. Sağlık personeli, hemodiyaliz hastaları, çok eşliler, intravenöz ilaç bağımlıları ve enfekte annelerden doğan bebekler bu risk gruplarını oluşturmaktadır (1-3). Genellikle parenteral yolla bulaşan Hepatit C virüsü (HCV) için bulaş yolları HBV ile aynıdır (4-7). Kan ve kan ürünleri transfüzyonu veya bunlarla temasın olması, intravenöz ilaç bağımlılığı, sosyoekonomik düzeyin düşük olması ve toplu kurumlarda yaşanması HBV için olduğu gibi HCV için de risk faktörleridir (8-10).

HBV akut, kronik ve fulminan hepatite ayrıca hepatoselüler kansere neden olan bir virüstür. Dünya üzerinde 450 milyon, ülkemizde ise üç milyon kişinin taşıyıcısı olduğu bilinmektedir (11,12). Dünyada HBV taşıyıcılığının ortalama \%6.5 olduğu bildirilmiştir.(13) Yurdumuz HBV taşıyıcılığı açısından orta endemisite bölgeleri (\%3-7) arasında yer almaktadır (14). Ülkemizde HBV taşıyıcılığı \% 2-10 arasındadır. Sağlık personelinde ise bu oranın 1,5-2 kat daha fazla olduğu bildirilmiştir. 14 Dünyada yaklaşık 300 milyon, ülkemizde ise 600 bin kişinin HCV ile enfekte olduğu tahmin edilmektedir $(15,16)$.

HCV prevalansı dünyada \%0,5-2 arasında değişmektedir. Türkiye'de ise raporlara göre değişmekle beraber kan donörlerinde \%0,3-0,5, sağlık personelinde ise \%1.6 olarak bildirilmektedir (13). HCV, HBV'ye göre daha düşük prevalansa sahip olmakla birlikte daha sık kronik hepatite ve siroza neden olabilen bir virüstür (11).

Tüm dünyada yaygın olarak görülen HCV enfeksiyonu, görülme sıklığı yönünden ülkeler arasında, hatta aynı ülkede bölgeler arasında farklılıklar göstermekle birlikte, sağlıklı kişiler veya kan donörleri arasında yapılan çalışmalarda \% 0,2-6 arasında değişen seropozitiflik bildirilmektedir $(17,18)$.

Sağlık çalışanları için HBV ve HCV enfeksiyonları meslek hastalığı olarak her zaman güncelliğini korumuşlardır. Hastalar ile daha yakın temas içinde çalışan hemşireler, yapmış oldukları işlerle bu hastalığı hastalarından alabilecekleri gibi hastalarına da bulaştırabilir. Özellikle sık yapılan invaziv girişimler riski arttırmaktadır $(19,20)$.

Sağlık çalışanları meslekleri nedeniyle özellikle HBV ve HCV bulaşması açısından risk altındadır. Bu virüslerle sağlık çalışanlarının enfeksiyonu daha çok kan ya da vücut sıvıları (parenteral), enfekte kişilerle yakın temas (horizontal) ve perkütan yaralanmalar ile ilişkilidir. Bunun yanı sıra diş hekimliği veya cerrahi operasyon sonucu damlacık yolu ve viremi ile de çapraz bulaşma olabileceği ileri sürülmektedir (13). HCV'nin bulaşmasında ayrıca son yıllarda nozokomiyal bulaş ve enfekte kan damlasının göze sıçraması da bulaş yollarından biri olarak kabul edilmektedir $(13,21,22)$. Bu risklerden dolayı sağlık çalışanlarının aşı ile korunulabilen HBV'ye karşı aşılanması gerekmektedir (23).

Araştırmamızda risk grupları içinde önemli bir yere sahip olan sağlık yüksekokulu öğrencilerinin hepatit seroprevelanslarını belirlemeyi, gerek görülen öğrencilere aşı yapmayı ve konuya dikkati çekmeyi planladık.

\section{Gereç ve Yöntem}

Çalışmamızda, 01.02.2013-10.04.2013 tarihleri arasında çalışmaya katılmayı kabul eden Sağlık Yüksek Okulu Öğrencilerine anket uygulandı. Anket soruları yaş, cinsiyet, kaçıncı sınıfta okuduğunu, sarılık geçirme öyküsü, ailede sarılık geçirme öyküsü, hepatit B'ye karşı aşılanma durumu, kronik hastalık varlığı, immunsupresif ilaç kullanım öyküsü, aile yapısı ve kardeş sayısını içermekteydi. HBsAg, Anti-Hbs, Anti-HBclgG ve Anti-HCV sonuçlarıyla birlikte değerlendirildi. HBsAg, Anti-Hbs, Anti-HBclgG ve Anti-HCV testleri "ECLIA" elektrokemilüminesans immünolojik test Cobas e411 analizör ROCHE Diagnostic ,Mannheim, Germany yöntemi ile çalışıldı. Istatistiksel analizler STATA 11,0 (College station, Texas, USA) bilgisayar programı ile yapıldı. Elde edilen veriler sayı ve yüzdelik hesaplama kullanılarak değerlendirildi. Grupların karşılaştırmas Fisher exact testi kullanılarak yapıldı. P değerinin <0,05 bulunması istatistiksel olarak anlamlı kabul edildi.

\section{Bulgular}

Sağlık Yüksek Okulunda okumakta olan 142 öğrenci çalışmaya alındı. Öğrencilerin 80'i $(\% 56,3) 1$. sınıf, 42'si $(\% 29,6)$ 2. sınıf, 9'u $(\% 6,3) 3$. sınıf, 11'i $(\% 7,8) 4$. sınıfta okumaktaydı ve

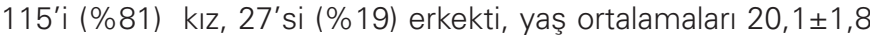
(18- 25 arası) idi.

HBs $2(\% 1,4)$ öğrencide pozitif bulundu. Anti-Hbs 127 $(\% 89,4)$ öğrencide pozitifti. Anti-HBclgG $9(\% 6,3)$ öğrencide pozitif saptandı. Anti-HCV öğrencilerin tümünde negatifti. Ailesinde sarılık geçirme öyküsü bulunan 17 öğrenciden birinde $(\% 5,9)$ Anti-HBclgG pozitif iken öykü bulunmayan 116 öğrenciden $8(\% 6,9)$ 'inde Anti-HBclgG pozitif bulundu ( $p=0,934)$. Sarılık geçirdiğini söyleyen yedi kişiden iki $(\% 28,6)$ 'sinin Anti-HBclgG pozitif bulundu, sarılık geçirmediğini söyleyen 135 kişiden yedi, $(\% 5,2)$ 'sinin Anti-HBclgG'si pozitif bulundu $(p=0,013)$. Anti$\mathrm{HBclgG}$ değeri pozitif bulunan dokuz öğrenciden ikisinin HBsAg pozitif kaldığı yedisinde ise Anti-HBs'nin pozitifleşmiş olduğu tespit edildi. Anti-HBs pozitifliği olan 127 öğrenciden 120'sinin $(\% 94,5)$ aşılama ile bağışıklık kazanmış olduğu bulundu. HBsAg, Anti-HBclgG ve Anti-HBs negatif bulunan $13(\% 9,2)$ öğrenci hepatit B aşılama programına alındı.

Hepatit B aşısı olup olmadıkları sorgulandığında öğrencilerden sadece 81'i (\%57) hepatit B aşısı olduğunu, 33'ü $(\% 23,2)$ bilmediğini, 28'i $(\% 19,7)$ ise olmadığını belirtmiştir. Hepatit B aşısı olmadığını belirten 28 kişiden 25'inde $(\% 89,3)$ Anti-HBs pozitif saptanmış ve bunlardan beşinde Anti-HBclgG pozitif bulunmuştur. Çalışma grubunda iki öğrencide diabetes mellitus mevcuttu, bu öğrencilerde bağışıklama ile elde edilmiş Anti-HBs pozitifliği saptandı. Steroid kullanım öyküsü olan yedi öğrencide Anti-Hbs pozitif, Anti-HBclgG negatifti.

Anti-HBclgG pozitif ve negatif olan öğrencilerde median kardeş sayısı iki olarak saptandı $(p=0,134)$. Öğrencilerden 124'ü çekirdek aile yapısına, 18'i geniş aile yapısına sahipti, bunlarda Anti-HBclgG pozitifliği sırasıyla \%5,6 ve \% 11,1 olarak bulundu $(p=0,386)$.

Öğrencilerin hiçbirinde HBsAg pozitif hastadan yaralanma öyküsü bulunmamaktaydı.

Bulguların özeti Tablo 1 de verilmiştir. 
Tablo 1. Bulguların özeti

\begin{tabular}{|c|c|c|c|c|}
\hline & Anti-HBclgG pozitif & Anti-HBclgG negatif & Toplam & $\mathbf{p}$ \\
\hline Ailede sarılık geçirme öyküsü + & $1(\% 59)$ & $16(\% 94,1)$ & $17(\% 100)$ & \multirow[b]{2}{*}{0,934} \\
\hline Ailede sarılık geçirme öyküsü olmayan & $8(\% 6,9)$ & $108(\% 93,1)$ & $116(\% 100)$ & \\
\hline Sarılık geçirme öyküsü + & $2(\% 28,6)$ & $5(\% 71,4)$ & $7(\% 100)$ & \multirow[b]{2}{*}{0,013} \\
\hline Sarılık geçirme öyküsü olmayan & $7(\% 5,2)$ & $128(\% 94,8)$ & $135(\% 100)$ & \\
\hline Geniş aile & $2(\% 11,1)$ & $16(\% 88,9)$ & $18(\% 100)$ & \\
\hline
\end{tabular}

\section{Tartışma}

Hepatit B virüsü (HBV) sağlık çalışanlarının risk altında olduğu bir patojendir (24,25). Her yıl Avrupa'da 304000 sağlık çalışanı HBV ile kontamine delici bir cisimle perkütan bir travmaya maruz kalmaktadır (26). En fazla risk altında olan kişiler, hekimler, laboratuvar, diyaliz ve acil ünitesi çalışanları, hemşireler, diş hekimleri ve kan bankası personelidir. Girişimsel işlemler sırasında sağlık personeline HBV bulaşma riski milyonda 2,4'tür (27). Amerika Birleşik Devletleri'nde kanla direkt teması olan medikal, dental ve laboratuvar çalışanlarında HBV prevalansı \%1-2 iken, kanla direkt teması olmayan sağlık personelinde prevalans \%0,3'tür (28). Ülkemizde de sağlık personeli riskli grupta olup, bu oran \%2-14 olarak bildirilmektedir (28).

Shin ve ark.'nın Kore'de sağlık çalışanlarında yaptıkları çalışmada HBsAg ve antiHBs seroprevalansı sırasıyla \%2,4 ve \%76,9 idi (29). Genellikle riskin en yüksek olduğu dönem eğitim dönemidir. Bu nedenle tıp, diş hekimliği, hemşirelik, laboratuvar branşları ve ilişkili dallarda eğitim gören öğrencilerin kan ve diğer vücut sıvıları ile temas etme riski ortaya çıkmadan önce aşı programları tamamlanmalıdır (30) Çalışmamız da eğitim döneminde olan sağlık yüksek okulu öğrencilerinde hepatit B ile aşılanma ve karşılaşma durumlarının belirlenmesi amaçlanmıştır.

Inci ve ark. 292 sağlık personelinin üçünde $(\% 1,0) \mathrm{HBsAg}$, 183 'ünde $(\% 62,7)$ anti-HBs pozitif olarak bulmuştur. $129(\% 44,2)$ kişide aşıya bağlı anti-HBs pozitifliği, 54 (\%18,5) kişide ise doğal anti-HBs pozitifliği saptanmıştır. HBV'ye karşı doktorların 19 $(\% 95,0)^{\prime} u$, ebe-hemşirelerin $90(\% 76,3)^{\prime}$ 'ı, teknisyenlerin 28 $(\% 68,3)^{\prime}$ i, temizlik şirketi çalışanlarının $25(\% 43,9)$ 'i ve diğer personelin 21 (\%37,5)'i bağışık olarak bildirmişlerdir (31).

Luksamijarulkul ve ark. sağlık çalışanları üzerinde yaptıkları çalışmada HBsAg pozitifliğini \%3,4 olarak bildirmişlerdir32. Karslıgil ve ark.'nın yaptığı çalışmada; hastane personelinde $\% 5,41$, normal populasyonda \%5,0 pozitiflik saptanmıştır (33). Ülkemizde sağlık personeline yönelik yapılan diğer çalışmalarda HBsAg pozitifliği 1,9-4,1\% arasında bulunmuştur (14,34-40).

Sağlık çalışanları arasındaki HBsAg pozitiflik oranlarını ise; Doğan ve ark. (41) diş hekimlerinde \%7,7, yardımcı sağlık personelinde \%8,2; Sarı ve ark. (42) temizlik personelinde $\% 4,4$; Pahsa ve ark. (43) hekimlerde \%1,3, hemşirelerde \%2,8, yardımcı sağlık personelinde ise \%3,6 olarak bildirmişlerdir. Çakaloğlu ve arkadaşları 1980- 2000 yıllarını kapsayan ve Türkiye'de sağlık çalışanları arasında yapılan çalışmaların derlendiği bir meta analiz çalışmasında 14,000 sağlık çalışanında
HBsAg seroprevalansının 1980-1990 yılları arasında \% 5,8 iken, 1990-2000 yılları arasında bu oranın \%3,6'ya gerilediğini saptamışlardır (44).

Inan ve ark. (45) yaptıkları çalışmada meslek gruplarına göre değerlendirme yaptıklarında kan ve vücut sıvılarıyla en fazla temasın hemşirelerde $(\% 29,1)$, en sık temas şeklinin de iğne batması $(\% 90,3)$ şeklinde olduğunu saptamışlardır. DSÖ sağlık çalışanlarının risk altında olmasından dolayı 1992'de HBV'yi meslek hastalığı olarak kabul etmiştir (23).

Kutlu ve ark Tıp fakültesi öğrencilerinde hepatit B prevelansı çalışmasında, öğrencilerde HBsAg pozitifliğinin \%0,7 olduğunu bildirmişlerdir (46).

Çetinkol ve arkadaşları 200 sağlık meslek lisesi öğrencisi üzerinde yaptıkları bir araştırmada $\mathrm{HBsAg}$ ve Anti-HCV pozitifliğine rastlamamışlar, anti-HBs \%89, anti-HAVIgG \%39,5 oranında pozitif saptamışlardır (47) Bizim çalışmamızda HBsAg $2(\% 1,4)$ öğrencide pozitif bulundu. Anti-Hbs $127(\% 89,4)$ öğrencide pozitifti. Çalışmamızda saptanmış olan Anti-Hbs pozitiflik oranı Çetinkol ve arkadaşlarının çalışmasına benzerdir. Düşük oranda bulunmuş olan HBsAg pozitifliği muhtemelen öğrencilerin henüz mesleklerinin öğrenme aşamasında olmaları ve hepatit B'ye karşı yüksek bağışıklanma oranına sahip olmaları nedeniyledir.

Çalışmamızda, Hepatit Başısı olup olmadıkları sorgulandığında öğrencilerden sadece 81'i (\%57) hepatit B aşısı olduğunu, 33'ü $(\% 23,2)$ bilmediğini, 28'i $(\% 19,7)$ ise olmadığını belirtmiştir. Hepatit B aşısı olmadığını belirten 28 kişiden $25^{\prime}$ inde $(\% 89,3)$ Anti-Hbs pozitif saptanmış ve bunlardan 5'inde Anti-HBclgG pozitif bulunmuştur. Bu sonuçlar göz önüne alındığında aşılama öyküsünü sorgulamanın güvenilir olmadığı, hepatit belirteçlerine bakılması gerekliliği düşünülebilir.

Bizim çalışmamızda, Anti-HBclgG $9(\% 6,3)$ öğrencide pozitif saptandı. Sarılık geçirdiğini söyleyen 7 kişiden 2 (\%28,6)'sinin Anti-HBclgG pozitif bulundu, sarılık geçirmediğini söyleyen 135 kişiden $7(\% 5,2)^{\prime}$ sinin Anti-HBclgG'si pozitif bulundu. Ailesinde sarılık geçirme öyküsü bulunan 17 öğrenciden birinde $(\% 5,9)$ Anti-HBclgG pozitif iken öykü bulunmayan 116 öğrenciden 8 $(\% 6,9)^{\prime}$ inde Anti-HBclgG pozitif bulundu. Bunlara dayanarak sorgulamada aile hikayesinden ziyade kişinin kendisinin sarılık geçirip geçirmediğinin belirtilmesi daha anlamlıdır.

Çalışma grubumuzun aile yapısı incelendiğinde, aile tipi ve kardeş sayısı ile Anti Hbc lgG arasında ilişki saptanmamıştır.

Sağlık çalışanlarında HCV enfeksiyonu ile ilgili çalışmalarda; 
Fransa'da seropozitivitenin cerrahlarda \%0,1-0,01, hemşirelerde ise \%0,054-0,0054 olduğu bildirilmiştir (45) Anti-HCV pozitifliği Parana ve ark. (48) nın çalışmasında \%2,8, Jindal ve ark (49) nın çalışmasında \%4,0 olarak bulunmuştur. HCV pozitifliğinin ülkemizde genel populasyonda \%1-2,4 arasında olduğu bildirilmiştir (21). Ülkemizde yapılan sağlık çalışanlarındaki Anti-HCV pozitiflik oranları 0-1\% arasında bulunmuştur $(34,35,38,41,42,50,51)$ Çalışmamızda öğrencilerin tümünde Anti-HCV negatifti.

\section{Sonuç}

Sonuç olarak sağlık personeli HBV ve HCV açısından risk altındadır. Öğrenim ve meslek yaşamları süresince her an risk altında bulunan sağlık hizmetleri öğrencilerinin hepatit $B$ ve C'nin bulaşma yollarını bilmeleri gerekmektedir. Sağlık çalışanları içinde en büyük riski taşıyan hemşirelerin hasta ile karşılaşmadan aktif bağışıklığının sağlanması gerekmektedir. HBV enfeksiyonu aşı ile önlenebilir bir hastalık olduğu için tüm çalışanların eğitimi ve özellikle HBV aşısından taranıp, bağışık olmayan kişilerin aşılanması önem taşımaktadır. Aşılanma oranı arttıkça personelin HBV enfeksiyonuna yakalanma ve enfeksiyonu diğer bireylere bulaştırma riski azalacaktır.

\section{Çıkar Çatış̧ması: Bildirilmemiştir. Kaynaklar}

1. Kılıçturgay K (ed). Hepatitis B epidemiyolojisi. Viral Hepatitle Savaşım Derneği, Istanbul. Viral Hepatit 94 1.Baskı, 1994; s:91101.

2. Kawai H, Feinstone SM. Acute viral hepatitis. In: Mandell GL, Bennett JE, Dolin R. Principles and Practice of Infectious Diseases. Philedelphia: Churchill Livingstone; 2000: 1279-1296.

3. Yenen OŞ. Viral hepatitler. Topçu AW, Söyletir G, Doğanay M (ed) Infeksiyon Hastalıkları Nobel Kitapevi 1996; s: 641-691.

4. Kalkan A, Kuloğlu M, Bahçecioğlu IH, Namlı M, Felek S. Psikiyatri hastalarında Hepatit B ve Hepatit C seroprevalansı. Viral Hepatit Derg. 1999; 1: 46-50.

5. Yakıncı G, Rota S, Aylı D, Çırak M, Sultan N. Hemodiyaliz hastalarında AntiHCV pozitiflik nedenlerinin araștırılması. Viral Hepatit Derg. 1998; 2: 131-133.

6. Durmaz R, Tecimer C, Durmaz B, Günal S, Temel I, Kızılkaya N. Anti HCV pozitivity among different risk groups in Malatya, Turkey. Infeks Derg. 1992; 6: 247-249.

7. Özyılkan E, Tatar G, Köseoğlu T, Özkuyumcu C, Kayhan B, Telatar H. Virüslere bağlı kronik karaciğer hastalıklarında hepatit B virüs üzey antijeni, anti HDV, anti HCV sıklığı Mikrobiyol Bült. 1993; 27: 308-313.

8. Çakaloğlu Y. Kılıçturgay $\mathrm{K}$ (ed) Hepatit $\mathrm{C}$ virüs infeksiyonu (C hepatiti) Epidemiyoloji-patogenezklinik-tedavi, Viral Hepatit Viral Hepatitle Savaşım Derneği, İstanbul 1. Baskı. 1994; s:191.

9. Pereira BJG, Milford EL, Kirkman RL, Levey AS. Transmission of hepatitis C virus by organ transplantation. N Eng J Med. 1991; 325: 454-460

10. Esteban JI, Gonzales A, Hernandez JM, et al. Evaluation of antibodies to hepatitis $\mathrm{C}$ virus in a study of transmission associated hepatitis. N Eng J Med. 1990; 323: 1107-1112.

11. Dilek I, Demir C, Bay A et al. Seropositivity rates of HBsAg, Anti-HCV, antiHIV and VDRL in blood donors in Eastern Turkey. Turk J Hematol. 2007; 24(1): 4-7.

12. Curry MP, Chopra S. Acute viral hepatitis. In: Mandell GL, Bennett JE, Dolin R eds. Principles and Practice of Infectious Diseases. Philadelphia: Churchill Livingstone. 2005: 1426-41.
13. Akca G. Diş Hekimliğinde Kan Yoluyla Bulaşan Viral Infeksiyonlar ve Önemi. Hastane Infeksiyonları Dergisi. 2008; 12:5-10.

14. Demir I, Kaya S, Demirci M, Cicioğlu-Arıdoğan B. Isparta ili sağlık personelinde hepatit B virus seropozitifliğinin araştırılması. Infeksiyon Derg. 2006; 20(3): 183-7.

15. Tekay F. Hakkari ilinde HBV, HCV ve HIV seroprevalansı. Dicle Tip Derg. 2006; 33(3): 170-3

16. Quer J, Esteban J. Epidemiology. In: Thomas HC, Lemon S, Zuckerman AJ eds. Viral Hepatitis. Massachusetts: Blackwell Publishing Co. 2005: 407-25.

17. Badur S. Hepatit $C$ virüsü infeksiyonunun serolojik tanısı. Klinik Derg 1990,3: 58-62.

18. Bayat N, Dinç E, Akdik I, Ağaç E, Çetmeli G, Şimşek F, Özdemir A. Kan donörlerinde anti HCV pozitifliği. Viral Hepatit Derg. 1999; 1: 54-55

19. Oktay S: Akut Viral Hepatitin Prodromal Dönemin Özellikleri. Istanbul Üniversitesi Istanbul Tıp Fakültesi Ic Hastalıkları Anabilim Dalı, Doktora Tezi. 1984; s: 1-8/29-41.

20. Fincancı M: Așı ile önlenebilen cinsel yolla bulaşan hastalıklar "Neyzi O, Yolsal N (ed.) Cinsel Yolla Bulaşan Hastalıklar Tanı ve Tedavi Rehberi", Insan Kaynaklarını Geliştirme Vakfı, Așama Matbaacllı.1997; s: 103-107.

21. Sünbül M. Tabak F, Balık I, Tekeli E eds. HCV enfeksiyonunun epidemiyolojisi ve korunma. Viral Hepatit: Viral Hepatitle Savașım Derneği Yayını. 2007: 208-19.

22. Demirtürk N. Hastane kaynaklı bir akut hepatit-C olgusu Infeksiyon Derg. 2003; 17(4): 491-3.

23. Akgül $G$, Gündüz $T$, Borand $H$, İspir $B, A v c ı$ Ötnü $A$. Hastane personellerinin hepatit $B$ hakkında bilgi düzeyleri ve HBV serolojik markerlerinin araştırılması. Viral Hepatit Derg. 2005; 10(1): 54-7.

24. Özgenç F. Vaccines of Hepatitis. Turkiye Klinikleri J Pediatr. 2007: 3(11): 65-69.

25. Akın L. Kan ve Kan Ürünleri Ille Bulaşan Hastalıkların Kontrolü. Eds: Güler Ç, Akın L. Halk Sağlığı Temel Bilgiler. 1. baskı. Ankara. Hacettepe Üniversitesi Yayınları. 2006; s: 940-943.

26. Puro V, De Carli G, Cicalini S, Soldani F, Balslev U, Begovac $J$, et al. European recommendations for the management of healthcare workers occupationally exposed to hepatitis B virus and hepatitis C virus. Euro Surveill. 2005: 10(10): 260-264.

27. Bonanni P, Pesavento, G, Boccalini S, Bechini A. Perspectives of public health: present and foreseen impact of vaccination on the epidemiology of hepatitis B. J Hepatol. 2003; 39: 224-9.

28. Mıstık R, Balık I. Türkiye'de viral hepatitlerin epidemiyolojik analizi. In: Kılıçturgay K, Badur S eds. Viral hepatit 2001. 1. Baskı. Ankara: Viral Hepatitle Savaşım Derneği Yayını. 2001: 10-55.

29. Shin BM, Yoo HM, Lee AS, Park SK. Seroprevalence of hepatitis $B$ virus among health care workers in Korea. J Korean Med Sci. 2006; 21(1): 58-62.

30. Kartal ED. Sağlık Personelinde Aşılama ve Kemoprofilaksi Turkiye Klinikleri J Inf Dis-Special Topics. 2010; 3(1): 54-61.

31. Inci M, Ayşe Aksebzeci AT, Yağmur G, Kartal B, Emiroğlu M, Erdem Y. Hastane çalışanlarında HBV, HCV ve HIV seropozitifliğinin Araştırılması. Türk Hijyen ve Deneysel Biyoloji Dergisi. 2009; 66 (2): 59-66.

32. Luksamijarulkul $P$, Watagulsin $P$, Sujirarat D. Hepatitis B virus seroprevalence and risk assessment among personnel of a governmental hospital in Bangkok. Southeast Asian J Trop Med Hyg. 2007; 76(1): 165-9.

33. Karslıgil T, Uygur O. Sağlık personeli ve toplumda hepatit B virüsüne karşı oluşan doğal bağışıklık ve immünizasyonla gelişen antikor düzeylerinin araştırılması. Gaziantep Üniversitesi Tıp Dergisi. 2007; 1: 31-4.

34. Şencan I, Şahin I, Kaya D, Bahtiyar Z. Yeni kurulan bir tıp fakültesi hastanesi'nde sağlık çalışanlarının hepatit B ve hepatit C seroprevalansı. Viral Hepatit Derg. 2003; 8(1): 47-50. 
35. Öksüz Ş, Yıldırım M, Özaydın Ç, Şahin I, Arabacı H, Gemici G. Bir devlet hastanesi çalışanlarında HBV ve HCV seroprevalansının araștırılması. ANKEM Derg. 2009; 23(1):30-3.

36. Kurt H, Türçapar N, Battal I, Tekeli E, Meço E. Yüksek risk grubunda olan sağlık çalışanlarında viral hepatit $(A, B, C, D)$ infeksiyon sıklığı. Viral Hepatit Derg. 1997; 1: 56-9.

37. Güzelant A, Kurtoğlu MG, Kaya M, Keşli R, Baysal B. Kan vericilerinde ve bir ağız-diş sağlığı merkezi çalışanlarında hepatit $B$, hepatit $C$ ve HIV seroprevalansı ile vericilerde risk faktörlerinin araştırılması. Infeksiyon Derg. 2008; 22(4): 189-95.

38. Bölükbaş FFÖ, Zeyrek $F$, Bölükbaş $C$ ve ark. Hasta bakımı ve hastane hijyeninden sorumlu sağlık personelinde HBV, HCV ve HIV sıklığı. Viral Hepatit Derg. 2004; 9(2): 89-92.

39. Kuru U, Turan Ö, Kuru N, Sağlam Z, Ulucaklı Ö, Candan I. Hastane çalışanlarında hepatitis B virusu infeksiyonu sıklığı. Türkiye Kliniği Gastroenterohepatoloji Derg. 1994; 5:182-7.

40. Çetinkaya F, Gürses N, Aydın M, Albayrak D. Çocuk hastanesi personelinde hepatit B seroprevalansı. Mikrobiyoloji Bül. 1994; 28: $246-9$

41. Doğan GB, Bayındır Y, Kayabaș Ü, Tekerekoğlu MS, Yoloğlu S, Ersoy Y. Dişhekimleri ve yardımcı sağlık personeli arasında hepatit B ve C seroprevalansı. Klimik Derg. 2005; 18(3): 121-4.

42. Sarı N, Günal O, Dizbay M, Hızel K, Aktaş F. Bir üniversite hastanesinde temizlikten sorumlu şirket elemanlarında ve sözleşmeli hemşirelerde HBsAg ve Anti-HCV sıklığının araştırılması. Viral Hepatit Derg. 2006: 11(3): 126-31.

43. Pahsa A, Erdemoğlu AG, Ozsoy MF, Emekdaş G, Özer MT, Kocabeyoğlu Ö. Sağlık çalışanlarında hepatit B ve C seroprevalansı. IX. Türk Klinik Mikrobiyoloji ve Infeksiyon
Hastalıkları Kongresi, Antalya, Kongre kitabı. 1999; 234.

44. Çakaloğlu Y. Hepatit B ulusal uzlaşma toplantı metinleri. 2005; 99-102.

45. Inan D, Günseren F, Selçuk K, Harman R, Keskin S, Çolak D. Akdeniz Üniversitesi sağlık çalışanlarının kan ve vücut sıvılarıyla mesleki teması. Viral Hepatit Derg. 2005; 10: 109-13.

46. Kutlu R, Çivi S, Aslan R. Tıp Fakültesi Kız Öğrencilerinde Kızamık, Kızamıkçık, Kabakulak ve Hepatit B Seroprevalansı. TAF Prev Med Bull. 2011; 10(5): 549-556.

47. Çetinkol Y, Yıldıım AA. Sağlık Meslek Lisesi Öğrencilerinde HBsAg, Anti-HBs, Anti-HCV ve Anti-HAV IgG Sonuçlarının Değerlendirilmesi. Viral Hepatit Dergisi. 2012; 18(1): 23-5.

48. Parana $R$, Paiva T, Leite MR et al. Infection with hepatitis $C$ virus among health care workers in the Brazilian Western Amazon Region (Rio Branco, State of Acre). Am J Trop Med Hyg, 2007; 76(1): 165-9.

49. Jindal N, Jindal M, Jilani N, Kar P. Seroprevalence of hepatitis C virus $(\mathrm{HCV})$ in health care workers of a tertiary care centre in New Delhi. Indian J Med Res. 2006; 123(2): 179-80.

50. Aşkar E. Sağlık çalışanlarında Hepatit B ve Hepatit C Seroprevalansı. Şişli Etfal Eğitim ve Araştırma Hastanesi Enfeksiyon Hastalıkları ve Klinik Mikrobiyoloji Kliniği, uzmanlık tezi, Istanbul, 2006; s: 12-24.

51. Doğanay $M$, Patıroğlu T, Utaş $C$ ve ark. Değişik gruplarda HBsAg, Anti-HCV, ve anti-HDV pozitifliğinin karşılaştııılması. Mikrobiyoloji Bül. 1993; 27: 107-12. 